\title{
Effect of climatic factors on sooty blotch, flyspeck intensity andfruit quality of apple (Malus domestica Borkh.)
}

\author{
Farrukh Ayaz Kayani, Noosheen Zahid*, Mehdi Maqbool, \\ Muhammad Jamil Ahmed, Abdul Hamid, Syed Zulfiqar Ali Shah and \\ Abid Yaqoob
}

Department of Horticulture, Faculty of Agriculture, The University of Poonch, Rawalakot, Azad Jammu \& Kashmir-Pakistan

*Corresponding author's email: noosheenag_12@yahoo.com

Citation

FarrukhAyazKayani, Noosheen Zahid, Mehdi Maqbool, Muhammad Jamil Ahmed, Abdul Hamid, Syed Zulfiqar Ali Shah and AbidYaqoob. Effect of climatic factors on sooty blotch, flyspeck intensity and fruit quality of apple (Malus domestica Borkh.). Pure and Applied Biology. Vol. 7, Issue 2, pp727-735. http://dx.doi.org/10.19045/bspab.2018.70091

\begin{tabular}{lllr}
\hline \hline Received: 10/04/2018 & Revised: 08/06/2018 & Accepted: 21/06/2018 & Online First: 25/06/2018 \\
\hline
\end{tabular}

Abstract

Effect of the selected climatic factors (temperature, humidity, sunshine) on sooty blotch (SB) and flyspeck (FS) intensity and fruit quality was verified in apple orchards during two consecutive years on three different experimental sites [Site I: Moderately plains (PothiBala); Site II: Northern slopes (Rawalakot city); Site III: Southern slopes (Drake)]. All the orchards were planted with cultivar 'Banky', and the trees were 12 years old at the time of this study. Morphological data revealed that high relative humidity along with rainfall increased the intensity of SB and FS attack. Significant $(P<0.05)$ differences were observed regarding the number of fruit set per tree and fruit weight on all the three sites under observation. Sites having abundant sunshine, less humidity and less rainfall showed significantly $(P<0.05)$ higher yield and less disease attack. High rainfall and high humidity showed a negative correlation with fruit quality. Moreover, high titratable acidity and ascorbic acid content also proved that more sunshine and less humidity affected the quality of apple fruits positively. Thus, from this study it can be concluded that the sites having more sunshine and less rainfall are suitable for planting apple orchards than the sites with less sunshine, high humidity and high rainfall.

Keywords: Disease intensity; Fruit quality; Humidity; Malus domestica Borkh; Rainfall

Introduction

A disease complex of sooty blotch (SB) and flyspeck (FS) is the majorthreatfor applesgrown in the sub-humid temperate regions [1]. SB and FS collectively form a complex fungal disease caused by three different fungal species. This fungal complex grows superficially on the upper cuticle layer of the apple fruit but do not penetrate inside the cuticle [2].This SB and
FS complex develops in a cluster with or without mycelia mat. It appears as dark smudge like blemishes on fruit surface [1]. Apples cultivated in thearea of Azad Jammu and Kashmirdid not show any blemishes before July which is the start of monsoon season. But after that fruitsstart blackening which widely covers the crop through the end of August, andresultantly the final fruit quality is badly affected. 
These blemishes usually reduce the cosmetic look and consumer acceptability. It has been reported previously that, the fluctuation of temperature, water availability, relative humidity, rainfall and light had impact on growth, yield and quality of fruit which could be avoided by selecting suitable sites for apple production [3-5].

Apple plantations atRawalakot, Azad Jammu and Kashmir are severely affected during the months of fruit maturity (August-September) as the level of humidity and rainfall is very high whileless sunshine is available during that particular period. All these factors boost the intensity of SB and FS during fruit maturity. But no studies have been conducted so far to address this issue in this region of Azad Jammu and Kashmir. Therefore, this comprehensive study was designed to investigate the effect of different environmental factors (temperature, humidity, sunshine) on SB and FS disease complex and fruit quality of apple.

\section{Materials and methods}

\section{Sites of orchards}

Studies were conducted in three orchards located at Rawalakot valley of District Poonch, Azad Jammu and Kashmir, at altitude of 1800-2000m, East longitude $73^{\circ}$ $75^{\circ}$ and North latitude $33^{\circ}-36^{\circ}$ under the foothills of Himalaya. Apple orchards were selected from three different locations (a)Site I: moderately plains(Pothi Bala) (b)Site II: Northern slopes (Rawalakot city)and (c) Site III: Southern slopes (Drake).All three orchards were planted with cultivar 'Banky', and the trees were 12 years old at the time of this study. Trees were approximately $3 \mathrm{~m}$ high. These orchards were chosen because of the high incidence of SB and FS in this area due to high humidity and high rain fall. They were planted in rows with a row to row distance of $1.2 \mathrm{~m}$ and plant to plant distance of $3.5 \mathrm{~m}$. Guard rows were marked on all four sides of orchard in order to minimize the border effect. Selected orchards were protected with wind breaks (almost $4 \mathrm{~m}$ tall).

\section{Meteorological data}

Data for temperature and relative humidity (morning, noon and evening) was collected at two days interval starting from the month of March to October during year 2015 and 2016, using a pocket weather tracker (Kestrel 4500 NV). Average sunshine/ light duration (number of hours) was recorded on visual basis. Data for monthly rainfall $(\mathrm{mm})$ was collected from Meteorological Department, District Poonch, Azad Jammu and Kashmir.

\section{Assessment of SB and FS intensity}

SB and FS intensity was rated separately according to the scale mentioned by Batzer et al. [6].

\section{Growth and quality of apples \\ Physical parameters \\ Number of fruits per tree}

Number of fruits was counted on all the selected branches of each tree. Branches were randomly selected from middle and all four sides of tree.

\section{Fruit weight (g)}

Average weight of individual fruit was measured with the help of digital weighing balance.

\section{Fruit diameter (cm)}

Average diameter of individual fruit was recorded with the help of Vernier caliper.

\section{Chemical parameters}

\section{Total soluble solids (TSS)}

TSS was determined by using hand refractometer (Model: No. 507-I, Tokyo, Japan). $10 \mathrm{~g}$ of apple pulp was ground by adding $40 \mathrm{ml}$ of water in a kitchen blender. Mixture was centrifuged at $5000 \mathrm{~g}$ for 5 min. Filtrate from the mixture was separated using a filter paper. A drop from the filtrate was placed on prism of refractometer to obtain the value of TSS [7]. Refractometer was calibrated with purified water before analysis.

\section{Titratable acidity $(\%)$}

Titratable acidity was measured using the remaining filtrate of TSS. A $5 \mathrm{ml}$ aliquot of filtrate was mixed with 2-3 drops of phenolphthalein and titrated with $0.1 \mathrm{~N}$ $\mathrm{NaOH}$ until the $\mathrm{pH}$ reached to 8.1 [8]. 


$$
\text { Titratable acidity }(\%)=\frac{\text { Volume of } 0.1 \mathrm{~N} \mathrm{NaOH} \text { used }}{\text { Volume of sample used }} \times 100
$$

\section{Ascorbic acid (mg/100ml)}

$10 \mathrm{ml}$ of juice was mixed with $90 \mathrm{ml}$ of 0.4 $\%$ oxalic acid. An aliquot of $5 \mathrm{ml}$ from the mixture was titrated against 2,6dichlorophenol indophenol dye until the colour changed to pink and persisted for 1015 seconds. Ascorbic acid was measured using the formula described in AOAC [8].

\section{Total sugars ( $\left.\mathrm{mg} \mathrm{100g}^{-1}\right)$}

Total sugars were measured by using a colorimetric method described by Abbasi [9].

\section{Statistical analysis}

Experimental layout was a randomized complete block design (RCBD) with three replicates and each replicate consisted of five apple trees. Data for SB and FS were subjected to square root transformation and then back transformed for presentation. Data was recorded for two consecutive years on the same trees with same branches and was pooled together before analysis. Analysis of variance (ANOVA) was carried out and tested for significant differences among treatments by Duncan's Multiple Range Test (DMRT) at $P<0.05$, using statistical analysis system $\mathrm{SAS}^{\circledR}$ version 9.1.

\section{Results and discussion Meteorological data}

Graphical presentation of temperature at three sites showed a higher temperature at site I that decreased at site III and remained low at site II during eight months (Figure $1)$.

Data on monthly average relative humidity at three sites from both years of apple orchards (March to October) showed a higher level of relative humidity at site II as compared to site I and site III (Figure 2). Relative humidity showed positive correlation with rainfall, SB and FS incidence (Table 1). This trend demonstrated that with the increase in rainfall, relative humidity amplified disease infection.

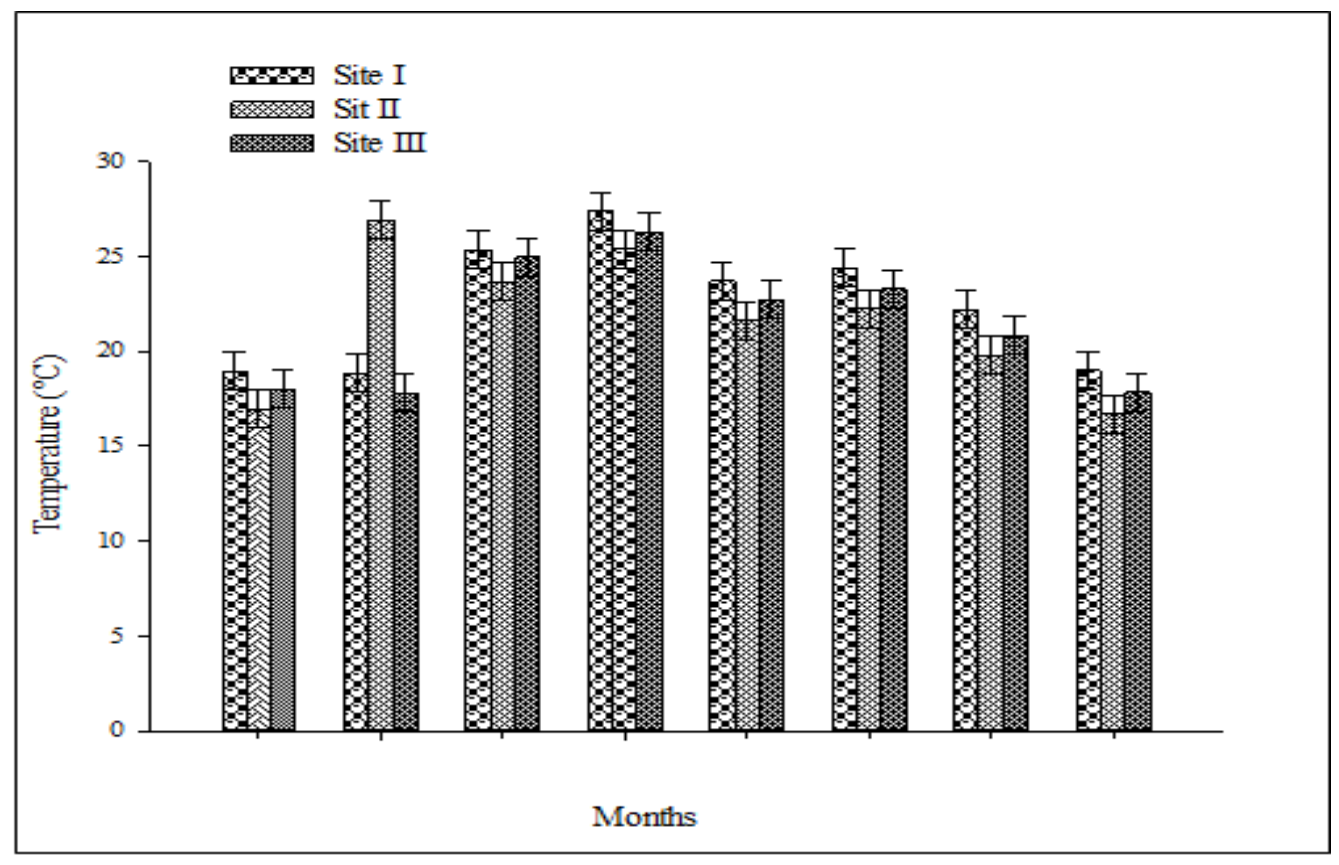

Figure 1. Monthly average temperature $\left({ }^{\circ} \mathrm{C}\right)$ at three sites of orchards during apple growing season (March-October) 


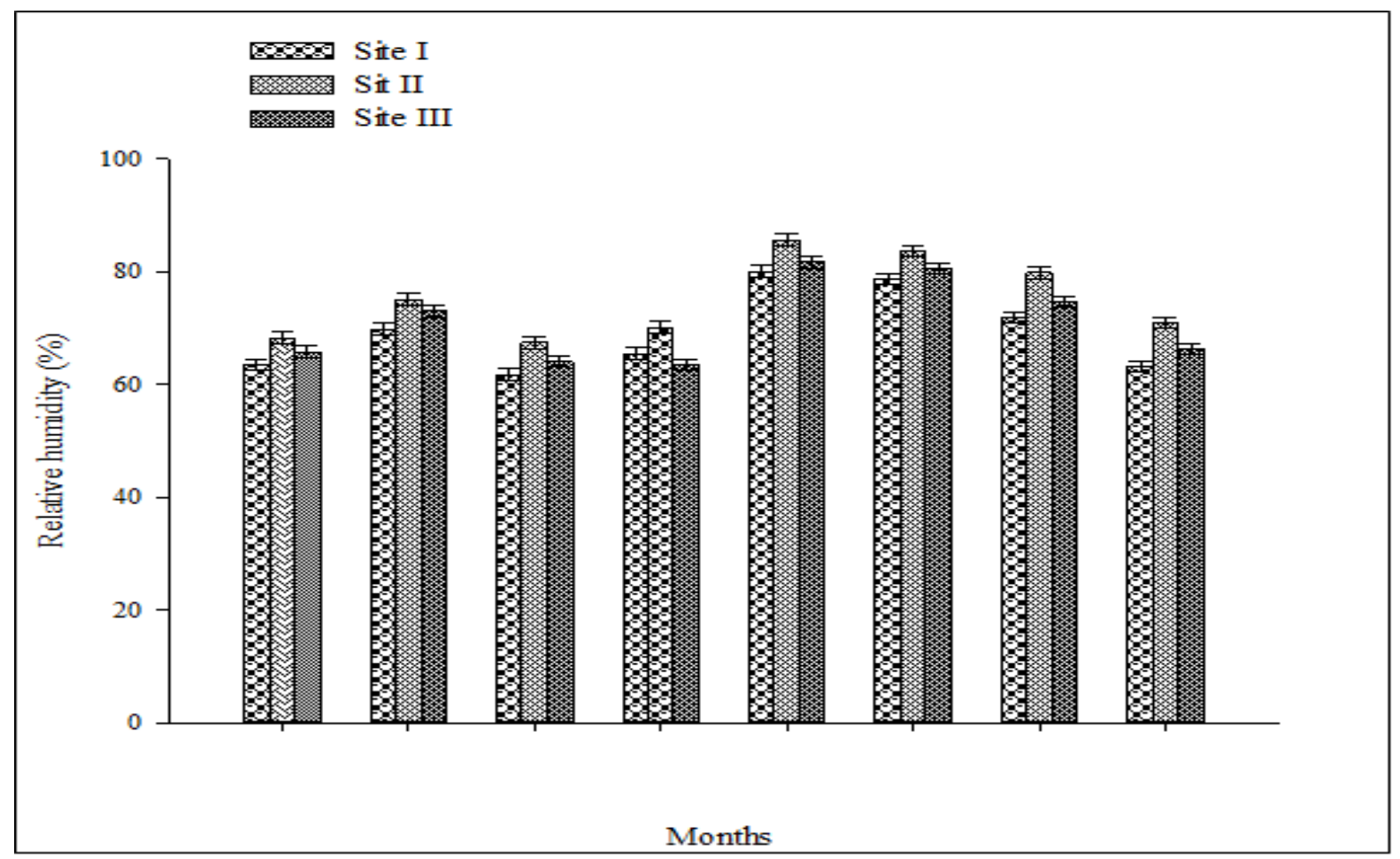

Figure 2. Monthly average relative humidity (\%) at three sites of orchards during apple growing season (March-October)

Growing season (March-October)

Data collected on monthly rainfall during the months of March to October at three sites of apple orchards remained higher at site II as compared to the other two sites
(Figure 3). Further, data on monthly sunshine hours at three sites of apple orchards showed more sunshine hours at site I throughout the recorded period of two years (Figure 4).

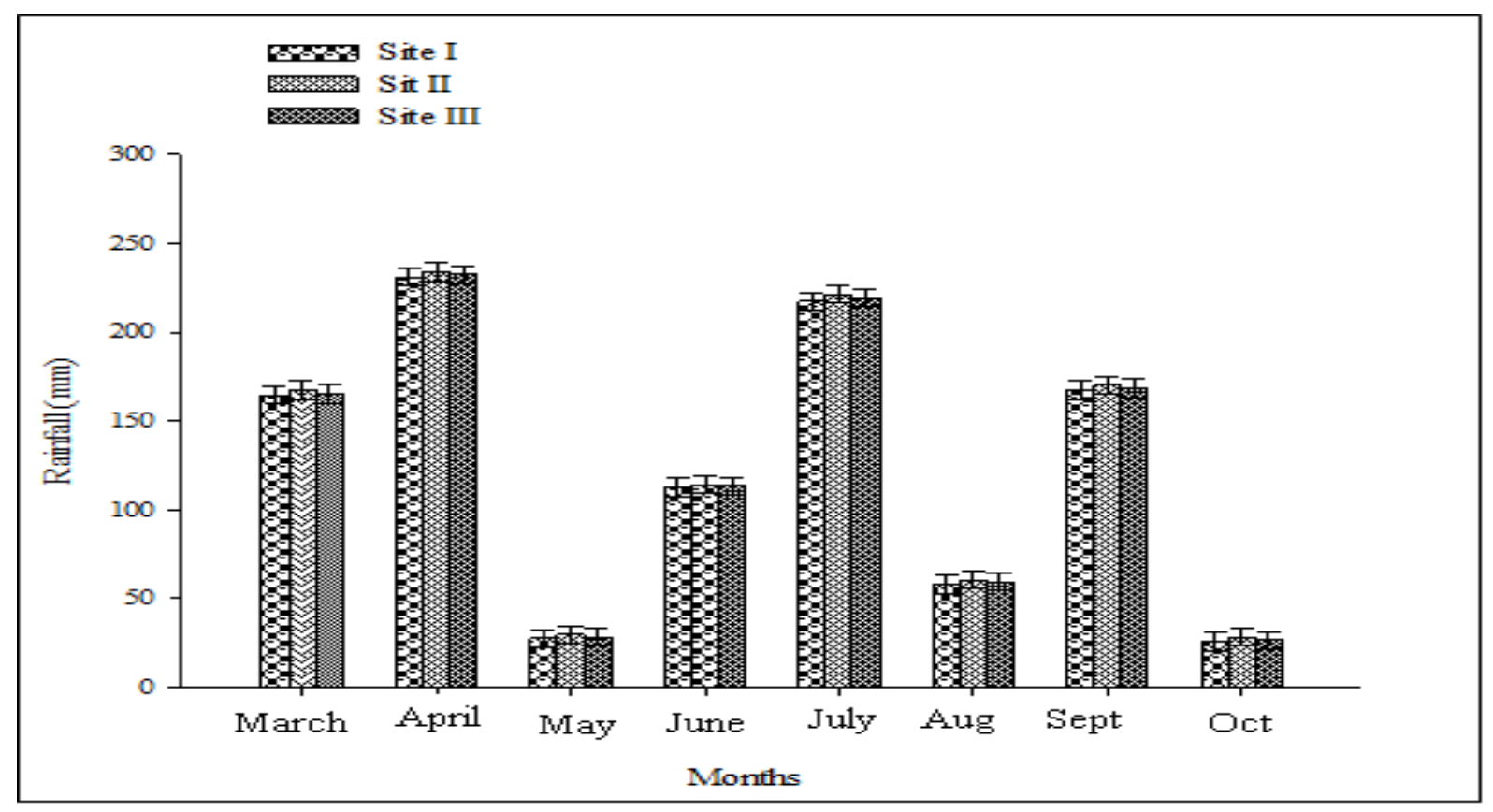

Figure 3. Monthly average rainfall $(\mathrm{mm})$ at three sites of orchards during apple growing season (March-October) 


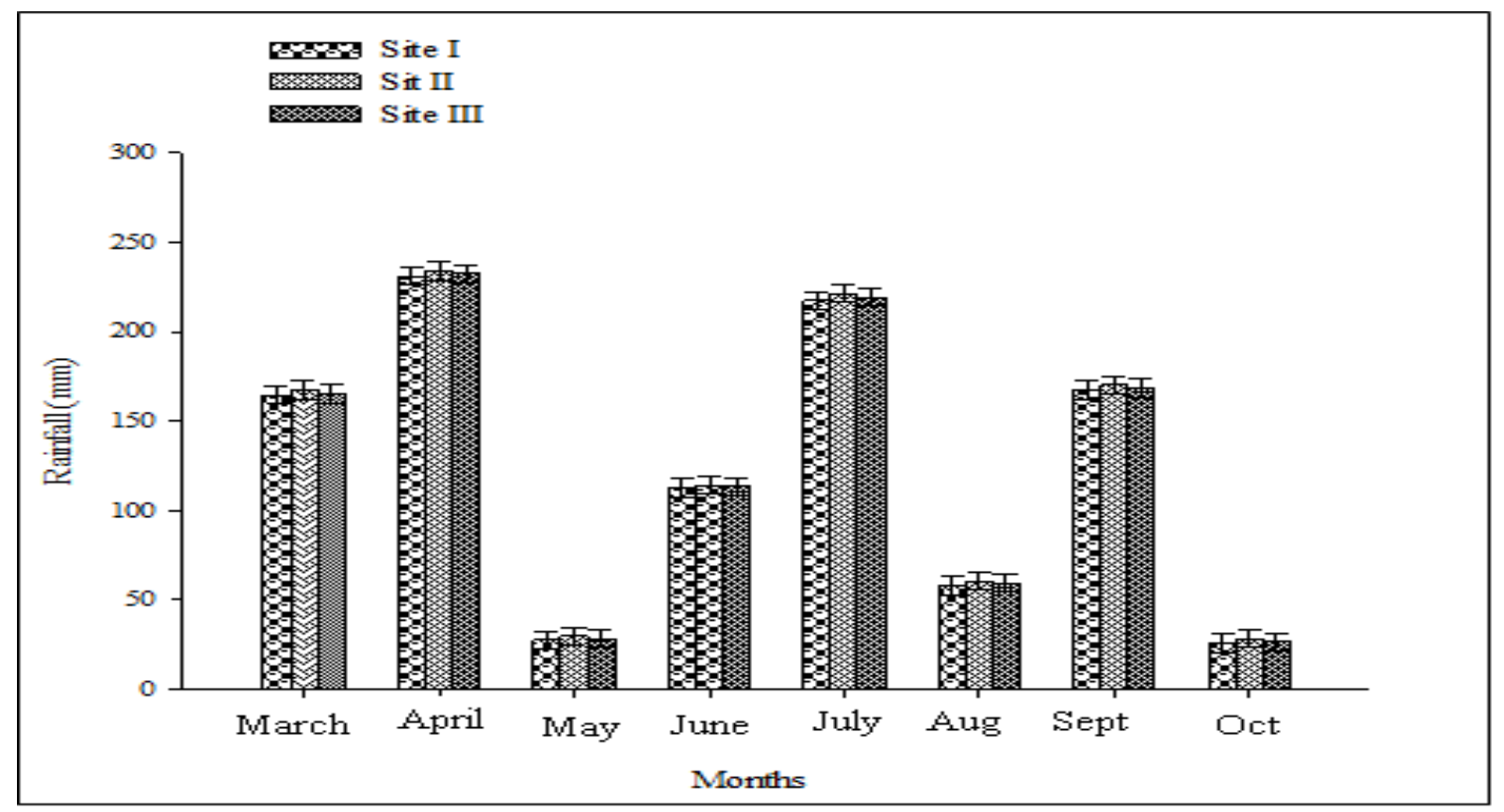

Figure 4. Monthly average sunshine (hours) at three sites of orchards during apple growing season (March-October)

Data collected on monthly rainfall during the months of March to October at three sites of apple orchards remained higher at site II as compared to the other two sites (Figure 3). Further, data on monthly sunshine hours at three sites of apple orchards showed more sunshine hours at site I throughout the recorded period of two years (Figure 4). From the simple correlation, it is clear that temperature has significant negative correlation with rainfall, $\mathrm{SB}, \mathrm{FS}$ and titratable acidity (Table 1). This shows that with increase in temperature SB and FS intensity was reduced. Whereas, the increase in rainfall increased the relative humidity of the orchard and also increased the disease incidence caused by SB and FS.

\section{Assessment of SB and FS intensity}

Results presented in table 2showed significant differences in SB and FS intensity. Maximum SB (51.30) was observed at site II that significantly $(P<$ $0.05)$ differed from the other two sites. SB showed positive correlation with FS and titratable acidity which means that rise in SB resulted in increase in FS (Table 1). It is clear from correlation studies (Table 1) and the results in (Table 2), that climatic condition affected the apple fruit quality with respect to disease infection. High relative humidity and rainfall increased the blotches intensity that was prevailing at Northern slope. These results are supported by Diaz Arias et al. [10] who reported that high humidity, precipitation and frost were associated with increase in disease infection. Moreover, Duttweiler et al. [11] also reported that high humidity, rainfall and frost occurrence increased the apple skin disorders. As SB and FS mainly occurs on waxy cuticle of the fruits and the sinks developed in the waxy layer of the fruit due to high humidity and temperature are the major cause for the attack of this fungus [11].

\section{Physical parameters}

Number of fruit set per tree

Results given in table 3 showed maximum number of fruits set per tree at site I which was significantly $(P<0.05)$ higher than site II, however, comparable with the results obtained from site III. It is evident from these results that optimum temperature, proper sunshine hours, less relative humidity and low rainfall at the time of flower bloom ensure maximum fruit setting at site I. Minimum number of fruit set per 
tree was recorded at site II that was due to lower temperature, high relative humidity, more rainfall and less sunshine hours particularly at the time of fruit setting.

Result recorded here showed that fruit set per tree significantly affected with climatic conditions, especially with temperature and light duration which was also confirmed by Miller et al. [3] and Lahlali et al. [12]. Paprstein et al. [13] also reported that, shading reduced fruit yield, red fruit color, soluble solids concentration, starch content, fruit length, width and weight in 'Delicious' apple.

\section{Fruit weight (g)}

Results presented in table 3 showed significant differences for fruit weight. Maximum fruit weight was observed at site I which was significantly $(P<0.05)$ higher than fruit weight at site II. Our results are in agreement with Miller et al. [3], who reported that shading by windbreaks and direction of apple fruits resulted in reduced fruit size and weight. This is due to the fact that fruit sinks are more sensitive to the shade than the vegetative growth [3].

\section{Fruit diameter (cm)}

Results regarding fruit diameter showed significant $(P<0.05)$ differences for fruit size among three different sites. Maximum fruit diameter was recorded at site I as compared to the other two sites (Table 3 ). These results showed that fruit diameter was significantly affected by climatic conditions, especially with temperature and sunshine hours (Table 1). It was also confirmed by Miller et al. [3] who reported that increased exposure to light increased the fruit diameter, TSS and flesh firmness. Increased fruit weight could be due to the less disease attack as SB \& FS complex as this fungus appears to modify the epicuticular wax layer of apple fruit, thereby causing faster water loss which results in reduced diameter of the fruit [14].

\section{Chemical parameters}

\section{TSS}

Maximum TSS was recorded at site I which was significantly $(P<0.05)$ higher from the other two sites (Table 4). Among three selected sites, minimum TSS was recorded at site II. It is clear from these results that temperature, proper sunshine hours ensure maximum TSS in apple fruits. These results are in accordance to Miller et al. [3] who reported that increased light duration maximized the amount of TSS and flesh firmness in apple fruits.

\section{Titratable acidity $(\%)$}

Maximum acid content in fruits were recorded at site II which was nonsignificantly $(P>0.05)$ different with site III (Table 4). It is clear from these results that less sunshine increased the acidity of apple fruits [13].

\section{Ascorbic acid (mg/100ml)}

Maximum ascorbic acid content were observed at site I which were significantly $(P<0.05)$ higher from the ascorbic acid content of site II and site III (Table 4). These results showed that climatic conditions affected the apple fruit quality with regard to ascorbic acid content that is an important quality parameter. Our results showed that ascorbic acid content was significantly affected by the climatic factors especially by the temperature and sunshine hours. It is also confirmed by Lee and Kadar [15] who reported that ascorbic acid content in plant tissues increased with increase in light intensity during growing season. As this amount of ascorbic acid relates with the maturity of fruit and the fruit trees having more shade due to wind breaks showed more ascorbic acid which suggests that fruit maturity advanced more quickly in those fruitas compared to others [3].

\section{Total sugars $(\mathbf{m g} / \mathbf{1 0 0 g})$}

Results presented in table 4clearly showed that values for total sugars were significantly $(P<0.05)$ different at all three sites. Maximum total sugars were recorded at site I, while the lowest total sugars were recorded in fruits harvested from site II. These results verified that climatic conditions affecting the apple fruit quality with regard to the amount of total sugars. High temperature resulted in increased sugar level with the reduction in acidity. All 
these climatic factors are responsible for FS \& SB complex. The SB \& FS complex is an epiphytic fungus which grows on waxy cuticle of apple fruit as well as on leaves and stems [14]. According to Belding et al. [16] SB \& FS obtain nutrients from apple exudates rather than from epicuticular components. Also, there is evidence that SB \& FS fungi are dependent on sugars and amino acids and this property of the fungus is responsible for reduced sugars and amino acids in highly infected fruits [17].

Table 1. Simple correlation coefficient among meteorological/ environmental data and fruit traits of apple

\begin{tabular}{|c|c|c|c|c|c|c|c|c|c|c|c|c|}
\hline & Temp & R.H & $\begin{array}{c}\text { Rain } \\
\text { fall }\end{array}$ & $\begin{array}{c}\text { Sunshin } \\
\text { e }\end{array}$ & $\begin{array}{l}\text { Fruit } \\
\text { tree }^{-1}\end{array}$ & $\begin{array}{l}\text { Sooty } \\
\text { blotch }\end{array}$ & $\begin{array}{c}\text { Fly } \\
\text { speck }\end{array}$ & $\begin{array}{c}\text { Fruit } \\
\text { weigh } \\
\text { t }\end{array}$ & $\begin{array}{c}\text { Fruit } \\
\text { size }\end{array}$ & TSS & $\begin{array}{c}\text { Ascorbi } \\
\text { c acid }\end{array}$ & $\begin{array}{c}\text { Total } \\
\text { sugar }\end{array}$ \\
\hline R.H & -0.98 & & & & & & & & & & & \\
\hline Rainfall & $-0.99 *$ & $0.99 *$ & & & & & & & & & & \\
\hline Sunshine & 0.95 & -0.88 & -0.91 & & & & & & & & & \\
\hline Fruit tree $^{-1}$ & 0.96 & $\begin{array}{c}- \\
0.99 *\end{array}$ & -0.98 & 0.84 & & & & & & & & \\
\hline $\begin{array}{l}\text { Sooty } \\
\text { blotch }\end{array}$ & -0.98 & $0.98 *$ & $0.98 *$ & $-0.99 *$ & -0.89 & & & & & & & \\
\hline Flyspeck & $-0.99 *$ & $0.98 *$ & $0.99 *$ & $-0.98 *$ & -0.91 & $0.99 *$ & & & & & & \\
\hline $\begin{array}{c}\text { Fruit } \\
\text { weight }\end{array}$ & $0.99 *$ & -0.95 & -0.97 & 0.98 & 0.92 & $-0.99 *$ & $1.00^{* * *}$ & & & & & \\
\hline Fruit size & $\begin{array}{c}1.00 * \\
*\end{array}$ & -0.98 & $0.99 *$ & 0.95 & 0.96 & -0.98 & $-0.99 *$ & $0.99 *$ & & & & \\
\hline TSS & $0.99 *$ & $\begin{array}{c}- \\
0.99 *\end{array}$ & $\begin{array}{c}- \\
1.00 * *\end{array}$ & 0.91 & $0.98 *$ & -0.95 & -0.96 & 0.96 & $0.99 *$ & & & \\
\hline $\begin{array}{l}\text { Ascorbic } \\
\text { acid }\end{array}$ & $0.99 *$ & $\begin{array}{c}- \\
0.99 *\end{array}$ & $\begin{array}{c}- \\
1.00 * *\end{array}$ & $0.99 *$ & $0.99 *$ & -0.95 & -0.96 & 0.96 & $0.98 *$ & $\begin{array}{c}1.00^{*} \\
*\end{array}$ & & \\
\hline Total sugar & $0.99 *$ & -0.95 & -0.97 & $0.99 *$ & 0.92 & $-0.99 *$ & $\begin{array}{c}- \\
1.00 * *\end{array}$ & $\begin{array}{c}1.00 * \\
* \\
\end{array}$ & $0.99 *$ & 0.97 & 0.96 & \\
\hline Acidity & $-0.99 *$ & 0.96 & 0.98 & -0.97 & -0.93 & $0.99 *$ & $0.99 *$ & $-0.99 *$ & $\begin{array}{c}- \\
0.99 *\end{array}$ & -0.97 & -0.97 & $-1.00 * *$ \\
\hline
\end{tabular}

*Correlation is significant at 0.05 level; **Correlation is significant at 0.01 level

Table 2. Sooty blotch and fly speck intensity (\%) on apple fruits grown at three different sites ( $\left(^{\dagger}\right)$

\begin{tabular}{|c|c|c|}
\hline Treatments & Sooty blotch (\%) & Fly speck (\%) \\
\hline Site I: Moderately plains (PothiBala) & $26.30 \mathrm{c}$ & $32.79 \mathrm{~b}$ \\
\hline $\begin{array}{c}\text { Site II: Northern slopes (Rawalakot } \\
\text { city) }\end{array}$ & $51.30 \mathrm{a}$ & $43.82 \mathrm{a}$ \\
\hline Site III: Southern slopes (Drake) & $42.33 \mathrm{~b}$ & $39.60 \mathrm{a}$ \\
\hline
\end{tabular}

Means with different letters in column are significantly different at $P<0.05$ using DMRT

Table 3. Number of fruits per tree, fruit weight and fruit size of apple fruits grown at three different sites $\left(^{\dagger}\right)$

\begin{tabular}{|c|c|c|c|}
\hline Treatments & $\begin{array}{c}\text { No. of fruits per } \\
\text { tree }\end{array}$ & $\begin{array}{c}\text { Fruit weight } \\
(\mathbf{g})\end{array}$ & $\begin{array}{c}\text { Fruit size } \\
(\mathbf{c m})\end{array}$ \\
\hline Site I: Moderately plains (PothiBala) & $310.33 \mathrm{a}$ & $124.84 \mathrm{a}$ & $6.84 \mathrm{a}$ \\
\hline $\begin{array}{c}\text { Site II: Northern slopes (Rawalakot } \\
\text { city) }\end{array}$ & $237.67 \mathrm{c}$ & $107.44 \mathrm{~b}$ & $5.79 \mathrm{~b}$ \\
\hline Site III: Southern slopes (Drake) & $292.67 \mathrm{a}$ & $114.52 \mathrm{ab}$ & $6.32 \mathrm{ab}$ \\
\hline
\end{tabular}

${ }^{\dagger}$ Means with different letters in column are significantly different at $P<0.05$ using DMRT 
Kayani et al.

Table 4.Total soluble solids, titratable acidity, ascorbic acid and total sugars of apple fruits grown at three different sites $\left({ }^{\dagger}\right)$

\begin{tabular}{|c|c|c|c|c|}
\hline Treatments & $\begin{array}{c}\text { Total soluble } \\
\text { solids }(\%)\end{array}$ & $\begin{array}{c}\text { Titratable } \\
\text { acidity }(\%)\end{array}$ & 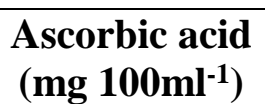 & $\begin{array}{c}\text { Total sugars } \\
\left(\mathbf{m g ~ 1 0 0 g}^{-1}\right)\end{array}$ \\
\hline $\begin{array}{l}\text { Site I: Moderately } \\
\text { plains (PothiBala) }\end{array}$ & $13.04 \mathrm{a}$ & $2.16 \mathrm{~b}$ & $17.73 \mathrm{a}$ & $15.33 \mathrm{a}$ \\
\hline $\begin{array}{l}\text { Site II: Northern slopes } \\
\text { (Rawalakot city) }\end{array}$ & $11.58 \mathrm{c}$ & $3.00 \mathrm{a}$ & $14.70 \mathrm{~b}$ & $11.20 \mathrm{c}$ \\
\hline $\begin{array}{l}\text { Site III: Southern slopes } \\
\text { (Drake) }\end{array}$ & $12.49 \mathrm{~b}$ & $2.63 \mathrm{a}$ & $15.40 \mathrm{~b}$ & $12.93 \mathrm{~b}$ \\
\hline
\end{tabular}

${ }^{\top}$ Means with different letters in column are significantly different at $P<0.05$ using DMRT

\section{Conclusions and recommendations}

In conclusion the present study indicates that the site which received high rainfall and high humidity during the months of fruit maturity, affected the fruit quality due to high infestation of SB and FS. It is recommended that in Azad Jammu \& Kashmir, apple orchards should be planted in plain and open areas where there is less humidity, low rainfall and abundant sunshine.

\section{Authors' contributions}

Conceived and designed the experiments: MJ Ahmed \& SZA Shah, Performed the experiments: FA Kayani \& A Yaqoob, Analyzed the data: FA Kayani \& N Zahid, Contributed materials/ analysis/ tools: SZA Shah \& A Hamid, Wrote the paper: FA Kayani, M Maqbool \& N Zahid.

\section{Acknowledgements}

Authors are thankful to Higher Education Commission (HEC), Pakistan for providing financial support.

\section{References}

1. Batzer JC, Diaz-Arias MM, Harrington TC, Gleason ML, Groenewald JZ \& Crous PW (2008). Four species of Zygophiala (Schizothyriaceae, Capnodiales) are associated with the sooty blotch and flyspeck complex on apple. Mycologia 100: 246-258.

2. Batzer JC, Sisson AJ, Harrington TC, Mayfield DA \& Gleason ML (2012). Temporal patterns in appearance of sooty blotch and flyspeck fungi on apples. MicrobEcol 64: 928-941.

3. Miller SS, Hott, C \&Tworkoski T (2015). Shade effects on growth, flowering and fruit of apple. J Appl Hort 17: 101-105.

4. Blažek J \& Hlušičková I (2003). Influence of climatic conditions on yields and fruit performance of new apple cultivars from the Czech Republic. Acta Hortic 622: 443-448.

5. Babadoost M (2005). Sooty blotch and Flyspeck of apple, Extension Specialist in Fruit and Vegetable Pathology, Department of Crop Sciences, University of Illinois, UrbanaChampaign 217: 333-1523.

6. Batzer JC, Gleason ML, Weldon B, Dixon PM \& Nutter FW Jr (2002). Evaluation of postharvest removal of sooty blotch and flyspeck on apples using sodium hypochlorite, hydrogen peroxide with peroxy acetic acid, and soap. Plant Dis 86: 1325-1332.

7. Maqbool M, Ali A, Alderson PG, Zahid N \& Siddiqui Y (2011) Effect of a novel edible composite coating based on gum arabic and chitosan on biochemical and physiological responses of banana fruits during cold storage. J Agric Food Chem 59: 54745482.

8. AOAC (2000). Official Methods of Analysis, Association of Analytical Chemists. Ed. 16 ${ }^{\text {th }}$ Arlington Virginia, USA.

9. Abbasi NA, Iqbal Z, Maqbool, M \& Hafiz, IA (2009). Postharvest quality of mango (Mangiferaindica L.) fruit as affected by chitosan coating. Pak J Bot 41: 343-357. 
10. Diaz Arias MM, Batzer JC, Harrington TC \& Wong AW (2010). Diversity and biogeography of sooty blotch and flyspeck fungi on apple in the Eastern and Midwestern United States. Phyto Pathol 100: 345-355.

11. Duttweiler KB, Gleason ML, Dixon PM, Sutton TB, McManus PS \& Monteiro JEBA (2008). Adaptation of an apple sooty blotch and flyspeck warning system for the Upper Midwest United States. Plant Dis 92: 12151222.

12. Lahlali R, Massart S, Serrhini MN \& Jijakli MH (2008). A Box-Behnken design for predicting the combined effects of relative humidity and temperature on antagonistic yeast population density at the surface of apples. Int J Food Microbiol 122: 100108.

13. Paprstein F, Blazek J \&Michalek S (2006). Effect of climatic conditions on fruit quality of apple cultivars, assessed by public sensory evaluations in the
Czech and Slovak Republics. J Fruit Ornam Plant Res 14: 219-227.

14. Gleason ML, Batzer JC, Sun GY, Zhang R, Díaz Arias MM, Sutton TB, Crous PW, Ivanović M, McManus PS, Cooley DR, Mayr U, Weber RWS, Yoder KS, Del Ponte EM, Biggs AR \&Oertel B (2011). A new view of sooty blotch and flyspeck. Plant Dis 95: 363 383.

15. Lee SK \& Kader AA (2000). Preharvest and postharvest factors influencing vitamin $\mathrm{C}$ content of horticultural crops. Postharvest Biol Technol 20: 207-220.

16. Belding RD, Sutton TB, Blankenship SM, \& Young E (2000). Relationship between apple fruit epicuticular wax and growth of Peltaster fructicola and Leptodontidium elatius, two fungi that cause sooty blotch disease. Plant Dis 84: 767-772.

17. Wrona B \& Grabowski M (2004). Etiology of apple sooty blotch in Poland. J Plant Prot Res 44: 293-297. 